\title{
УМОВИ ТА ПІДСТАВИ ЗАСТОСУВАННЯ ПРОЦЕДУРИ МЕДІАЦІЇ В КРИМІНАЛЬНОМУ ПРОВАДЖЕННІ
}

Гочачко І. М.

у статmі висвітлене питання актуальності та ефективності застосування процедури медіаціі у кримінальному провадженні. Автор аналізує основні характеристики медіації як способу примирення потерпілого $і$ правопорушника та розглядає iї переваги над судовим вирішенням спору.

Окремо у статmі приділяється увага питанню впровадження інституту медіації в кримінальному процесуальному законодавстві України. Автор досліджує у статmі регламентацію процедури примирення у кримінальному провадженні. 3'ясовано, що правовою підставою для застосування медіації $\epsilon$ глава 35 КПК України, що регулює укладення угоди про примирення між потерпілим та підозрюваним чи обвинуваченим. Окремо проаналізовано статmі 45 та 46 КК України, які також вказують на можливість проведення медіації з огляду на те, що звільнення особи від відповідальності передбачає необхідність примирення сторін та відшкодування збитків.

Крім того, у статmі автором зазначені умови використання процедури медіації в кримінальному провадженні, до яких належать обмежене коло злочинів, щодо яких можливе застосовування процедури медіації, ініціювання процедури медіації лише сторонами конфлікту, дотримання основних принципів проведення медіації та проведення медіації уповноваженими особами.

У cmammi виявлено та досліджено проблемні аспекти застосування процедури медіаціі, зокрема, відсутність чіткого порядку проведення процедури медіації, невизначений правовий статус медіатора у кримінальному провадженні, його прав, обов'язків та відповідальності. Автор звертає увагу на відсутність у кримінальному процесуальному законодавстві чіткого нормативного закріплення процедури медіаціі. 3 урахуванням проведеного аналізу та з огляду на ефективність застосування медіаційної процедури зроблені висновки щодо необхідності вдосконалення інституту медіації в кримінальному провадженні та чіткого нормативного закріплення підстав та порядку застосування процедури медіації.

Ключові слова: альтернативне вирішення спорів, медіація, кримінальне провадження, угода про примирення.
Hochahko I. M. Conditions and grounds for the application of the mediation procedure in criminal proceedings

The article highlights the issues of relevance and effectiveness of the use of mediation in criminal proceedings. The author analyzes the main characteristics of mediation as a method of reconciliation between the victim and the offender and considers its advantages over the court decision of the dispute.

Separately, attention was paid to the introduction of the institution of mediation into the criminal procedure legislation of Ukraine. The author examines in the article the regulation of the conciliation procedure in criminal proceedings. It was established that the basis for the use of mediation is Chapter 35 of the Criminal Procedure Code of Ukraine, which regulates the conclusion of an agreement on reconciliationbetweenthevictimand thesuspector theaccused. Separately analyzed Articles 45 and 46 of the Criminal Code of Ukraine, which also indicate the possibility of mediation in view of the fact that the release of a person from liability presupposes for the need for reconciliation of the parties and compensation for damages.

In addition, in the article, the author indicates the conditions for using the mediation procedure in criminal proceedings, which include a limited range of crimes for which the mediation procedure can be used, only the parties to the conflict can initiate mediation procedures, compliance with the basic principles of mediation and mediation can be conducted only by authorized persons.

In the article, the problematic aspects of the application of the mediation procedure were discoveredandinvestigated, in particular, the lack of a clear procedure for carrying out the mediation procedure, the uncertain legal status of the mediator in criminal proceedings, his rights, duties and responsibilities. The author draws attention to the lack of a clear normative stipulation of the procedure for the implementation of mediation have been identified and investigated. Taking into account the conducted analysis and the effectiveness of the mediation procedure, conclusions were made on the need to improve the institution of mediation in criminal proceedings and a clear normative consolidation of the grounds and procedure for applying the mediation procedure.

Key words: alternative dispute resolution, mediation, criminal proceedings, conciliation agreement. 
Постановка проблеми та іï актуальність. Медіація $\epsilon$ ефективним та найбільш поширеним у світі альтернативним способом врегулювання конфліктних ситуацій. Ефективність та переваги медіації сприяли як іï територіальному поширенню, так і розширенню сфери застосування медіації, зокрема, на кримінальне провадження.

Процедура медіації використовується в Україні вже тривалий час, однак досі продовжують існувати спірні моменти щодо організаційного та процесуального характеру, які впливають на застосування процедури примирення в кримінальному провадженні. Проблеми здійснення медіаційної процедури пов'язані з відсутністю детальної регламентації порядку проведення процедури медіації в кримінальному процесуальному законодавстві України, обмеженим колом кримінальних справ, щодо яких можна здійснювати медіацію, та незакріпленим процесуальним статусом медіатора.

Аналіз останніх досліджень i публікацій. Питання впровадження та застосування процедури медіації в кримінальному провадженні досліджувались такими видатними науковцями, як А.А. Арутюнян, Ю.В. Баулін, І.А. Войтюк, В.В. Землянська, Р.Г. Коваль, В.Т. Маляренко, М.В. Руденко, З.В. Симоненко, Н.О. Турман.

Ïхні наукові праці сприяли вдосконаленню інституту медіації в кримінальному процесі України та подальшому розвитку дискусій щодо впровадження інституту медіації в кримінальне процесуальне законодавство.

Метою статті $\epsilon$ дослідження нормативного закріплення процедури медіації в кримінальному законодавстві України, умов здійснення медіації, iï практичного застосування та виявлення спірних питань у разі реалізації інституту медіації в кримінальному провадженні та шляхів їх вирішення.

Виклад основного матеріалу. Поняття «медіація» досить відоме у світі і його тлумачать як один із альтернативних способів врегулювання спорів. Основною ознакою медіації $\epsilon$ залучення до вирішення спору незалежної та неупередженої сторони - медіатора, який буде керувати процедурою медіації та допомагати налагоджувати процес комунікації між сторонами спору.

Застосування медіації має низку переваг перед судовим вирішенням спору. До них належать такі. Вирішення конфлікту безпосередньо сторонами, що в результаті сприяє добровільному виконанню домовленостей. Також відсутні жорсткі процесуальні правила. Це сприяє тому, що сторони не відчувають напругу та дискомфорт, навпаки, атмосфера мирного врегулювання спору схиляє до співпраці. Крім цього, медіаційна процедура характеризується короткими термінами здійснення, що дозволяє сторонам зберегти час, гроші та спокій. Медіація $\epsilon$ конфіденційною, а тому всі факти та обставини, виявлені в ході ії проведення, не можуть бути розголошені та жодним чином не нашкодять сторонам конфлікту.

3 огляду на особливості кримінального права медіація у цій сфері набуває своїх особливих ознак. Зокрема, на думку 3.Д. Смітієнка, медіація в кримінальному процесі спрямована на досягнення примирення між потерпілим і правопорушником, усвідомлення протиправної поведінки та відшкодування заподіяної шкоди. Крім цього, науковець звертає увагу, що медіація дає змогу потерпілому виказати правопорушнику свої переживання, що допоможе потерпілому зменшити психологічну напругу та позбутись страху [1, с. 131].

Завдяки своїм перевагам та ефективності медіація заслужено отримала своє місце у вирішенні кримінально-правових конфліктів та стала одним зі способів примирення потерпілого і правопорушника.

Чинне кримінально-процесуальне законодавство України прямо не згадує поняття медіації, також відсутня пряма вказівка на право сторін застосовувати медіацію в кримінальному процесі. Однак хоч і не прямо, проте Кримінальний процесуальний кодекс України (далі - КПК України) однозначно дає можливість сторонам використати медіацію для вирішення конфлікту, зокрема, передумови для цього закладені в інституті примирення сторін.

Підставою для проведення медіації між потерпілим та правопорушником є глава 35 КПК України, що регулює укладення угоди про примирення між потерпілим та підозрюваним чи обвинуваченим. На можливість залучення медіатора до укладення угоди вказує зміст ч. 1 ст. 469 КПК України: «домовленості стосовно угоди про примирення можуть проводитися самостійно потерпілим і підозрюваним чи обвинуваченим, захисником і представником або за допомогою іншої особи, погодженої сторонами кримінального провадження (крім слідчого, прокурора або судді)» [2].

Процедуру медіації може бути ініційовано не тільки для укладення угоди про примирення сторін, а й також для звільнення порушника від кримінальної відповідальності у зв'язку з дієвим каяттям або у зв'язку з примиренням винного 
з потерпілим, що передбачено ст.ст. 45, 46 Кримінального кодексу України (далі - КК України).

Статтею 45 КК України передбачено, що особа, яка вперше вчинила злочин невеликої тяжкості, звільняється від кримінальної відповідальності, якщо вона після скоєння злочину щиро покаялася, активно сприяла розкриттю злочину і повністю відшкодувала завдані нею збитки або усунула заподіяну шкоду [3].

Статтею 46 КК України передбачено, що особа, яка вперше вчинила злочин невеликої тяжкості, звільняється від кримінальної відповідальності, якщо вона примирилася з потерпілим та відшкодувала завдані нею збитки або усунула заподіяну шкоду.

Так, у судовій практиці, зокрема, в ухвалі Заводського районного суду м. Дніпродзержинська Дніпропетровської області від 16.01.2020 року у справі №208/8462/19 [4] та в ухвалі Оболонського районного суду м. Києва від 20.06.2018 року у справі № 756/6864/18 [5], зазначено, що ст. 46 КК України $€$ закріпленням інституту медіації як альтернативного способу врегулювання кримінальноправових конфліктів, в основу якого покладено посередництво у примиренні сторін. Кримінальні провадження було закрито у зв'язку з примиренням винного з потерпілим.

Таким чином, статті 45 та 46 КК України також вказують на можливість проведення медіації з огляду на те, що звільнення особи від відповідальності передбачає примирення сторін та відшкодування збитків.

Можливість проведення медіації з метою укладення угоди обмежено визначеним колом випадків. Відповідно до ч. 3 ст. 469 КПК України до них належать провадження щодо кримінальних проступків, провадження щодо злочинів невеликої чи середньої тяжкості та кримінальне провадження у формі приватного обвинувачення. Також передбачено заборону укладення угоди про примирення у кримінальному провадженні щодо уповноваженої особи юридичної особи, яка вчинила кримінальне правопорушення, у зв'язку з яким здійснюється провадження щодо юридичної особи.

Такий перелік обґрунтовується тим, що ці кримінальні порушення не несуть великої суспільної небезпеки та для них головне - відшкодувати збитки та відновити емоційний стан потерпілого до скоєння злочину [6].

У зв'язку з цим серед науковців часто виникають розбіжності думок стосовно того, до яких злочинів можна застосовувати процедуру медіації. Наприклад, Р.В. Новак звертає увагу, що розши- рення можливостей закриття кримінального переслідування внаслідок примирення між потерпілим та обвинуваченим може спровокувати спроби незаконного тиску на потерпілого і навіть вчинення щодо нього нових суспільно небезпечних діянь з метою змусити його дати згоду на «примирення». Тому потрібно здійснити ретельний вибір категорій кримінальних правопорушень у провадженнях, де буде можливим примирення потерпілого з обвинуваченим чи підозрюваним [7, с. 93].

Також обмежено коло ініціаторів проведення медіації. Відповідно до ч. 1 ст. 469 КПК України укладення угоди про примирення може здійснюватися лише за ініціативою потерпілого, підозрюваного або обвинуваченого. Це положення впроваджено з метою дотримання принципу добровільності участі сторін у проведенні медіації, що має убезпечити сторони від тиску з боку правоохоронних органів. Кримінальним процесуальним законодавством встановлено також часовий проміжок для проведення медіації. Згідно з ч. 5 ст. 469 КПК України, ініціювати укладення угоди про примирення можна в будь-який момент після повідомлення особі про підозру до виходу суду до нарадчої кімнати для ухвалення вироку.

Хоч КПК України і не згадує про це, проте ще однією умовою для застосування медіації в кримінальному провадженні $€$ дотримання основних принципів проведення медіації та проведення медіації тільки уповноваженими та незалежними особами.

До принципів медіації належать добровільність, конфіденційність, доступність, незалежність та автономність.

Відповідно до принципу добровільності медіація має застосовуватися тільки у разі, коли всі сторони добровільно надали згоду на їі проведення. Так, кожна сторона самостійно та без будь-якого тиску приймає рішення щодо участі в процедурі медіації, а також усвідомлює можливість припинення медіації на будь-якому ії етапі. Суди неодноразово звертали увагу, що у разі коли укладення угоди не було добровільним, то угода затвердженню не підлягає. Зокрема, в ухвалі Дунаєвецького районного суду Хмельницької області від 08.10.2019 року у справі № 674/1473/19 зазначено, що сторони вказали, що ініціатором укладення угоди про примирення був слідчий [8]. У зв'язку з порушенням принципу добровільності у затвердженні мирової угоди було відмовлено, а судове провадження продовжене.

Принцип конфіденційності полягає в тому, що будь-яка інформація та документи, отримані 
в ході проведення медіації, мають конфіденційний характер та не будуть розголошені сторонами та медіатором, розголошення інформації можливе лише за згодою учасників медіації. 3 огляду на це, деякі науковці навіть пропонують внести медіаторів до переліку осіб, щодо яких неможливе проведення допиту у розрізі їхньої професійної діяльності та щодо фактів, про які вони дізналися у процесі проведення медіації [9, с. 651].

Медіація у кримінальних справах має бути доступним заходом. Доступність медіації означає, по-перше, що особа має бути повідомлена про можливість проведення медіації, та по-друге, особа за будь-яких обставин повинна мати можливість отримати послуги з проведення медіації на будь-якій стадії здійснення правосуддя.

Не менш важливим $\epsilon$ те, що проведення медіації має здійснюватися незалежно та автономно. Такий принцип полягає в тому, що медіація проводиться незалежно від судового розгляду справи і навіть може йому передувати. Незалежність проведення медіації забезпечується також з огляду на те, що медіатор $\epsilon$ залученою особою, що не буде симпатизувати та не займе позицію жодної зі сторін, а навпаки, буде намагатися рівною мірою допомогти всім учасникам медіації.

На думку Р.Г. Коваля, інститут медіації стане справді ефективним у впровадженні у систему кримінального судочинства принципів медіації, що містяться у Резолюції Економічної та Соціальної Ради ООН «Про основні принципи програм відновного правосуддя у кримінальних справах» від 24 липня 2002 р. та у Рекомендації Ради Європи № R (99) 19 щодо принципів організації медіації у кримінальних справах. Особливу увагу науковець звертає на такі, як активне залучення сторін до власного розв'язання питань кримінальної ситуації, увага щодо потреб потерпілої сторони та її активна участь у визначенні наслідків злочину, безпосередня участь сторін у виправленні наслідків скоєного та запобіганні повторенню злочинної поведінки у майбутньому [10, с. 11].

Зазначимо, що Н.О. Турман також наголошує на необхідності включення засад співпраці та рівноправності сторін. На її думку, принцип співпраці полягає в залученні в процес медіації всіх сторін, які своєю чергою докладають усіх зусиль для вдалого врегулювання спору, а принцип рівноправності означає надання сторонам рівнозначних прав та відсутність переваг [11, с. 277].

Дотримання згаданих вище принципів $є$ важливим у разі застосування медіації, особливо коли ми говоримо про кримінальний процес.
У ч. 1 ст. 469 КПК України перелічено учасників медіації в кримінальному процесі, до яких належать:

1) потерпілий i підозрюваний (якщо медіація відбувається на стадії досудового розслідування) чи обвинувачений (якщо медіація проводиться на стадії судового розгляду);

2) захисник і представник;

3) інші особи, погоджені сторонами кримінального провадження (крім слідчого, прокурора або судді).

Обов'язковими учасниками медіації $\epsilon$ потерпілий та підозрюваний або обвинувачений. Водночас положення КПК України передбачає можливість участі захисника і представника, не зазначаючи, чи вони будуть допоміжними учасниками, чи будуть заміняти потерпілого та правопорушника під час медіації. У разі якщо представники сторін будуть брати участь у медіації замість сторін, то така процедура медіації не буде здійснена з повним дотриманням принципів проведення медіації, зокрема, співпраці сторін та їх залучення до вирішення конфлікту.

3 огляду на сутність медіації, то вона завжди відбувається із залученням ще однієї нейтральної сторони - посередника. Незважаючи на те, що ч. 1 ст. 469 КПК України не вказує на пряму можливість залучення медіатора, проте ії можна помітити в залученні «інших осіб» до укладення угоди про примирення. Перелік таких осіб не конкретизовано, а отже, до них може належати й медіатор.

Натомість пряму заборону проводити медіацію передбачено в ч. 1 ст. 469 КПК України: домовленості стосовно угоди про примирення не можуть проводитись за допомогою слідчого, прокурора та судді. Ця норма $є$ втіленням принципу об'єктивності та неупередженості, адже залучена особа зобов'язана допомогти сторонам вирішити спір, не надаючи переваг жодній зі сторін.

У науковій спільноті $\epsilon$ й вчені, що виступають проти такої заборони. Наприклад, А.В. Лапкін вважає доцільним проведення медіації за допомогою прокурора. Він переконаний, що прокурори можуть успішно проводити примирення потерпілого та правопорушника самостійно, без залучення будь-яких інших осіб. Така думка ґрунтується на твердженні, що у разі проведення процедури примирення сторін прокурор не виступає на боці жодної сторони, оскільки принцип публічності унеможливлює його особисту зацікавленість у справі [12, с. 6-7]. 3 такою думкою важко погодитися, адже прокурор $є$ державним службовцем, а його інтерес може полягати у швидкому 
та успішному закритті справи, крім цього, прокурор залежить та підпорядковується вищестоящим посадовим особам, які можуть здійснювати тиск на прокурора для покращення статистичних даних щодо розкриття злочинів.

Для дотримання медіаторами принципу нейтральності та незалежності під час виконання своїх обов'язків вважаю за необхідне передбачити ще одне правило - медіатор не може проводити медіацію у разі наявності сімейних стосунків з однією зі сторін конфлікту, суперечності між його особистими інтересами та інтересами сторін, зацікавленості в результаті медіації. Тобто медіацію не може проводити особа, що має конфлікт інтересів. Водночас необхідно не просто закріпити таку норму, потрібно передбачити порядок повідомлення про наявність конфлікту та можливість перевірки таких фактів.

Висновки. Правовою підставою для проведення медіації між потерпілим та правопорушником є глава 35 КПК України, що регулює укладення угоди про примирення між потерпілим та підозрюваним чи обвинуваченим. Також застосування медіації може знаходити своє відображення через дієве каяття (ст. 45 КК України) або у зв'язку з примиренням винного з потерпілим (ст. 46 КК України).

Проведення медіації у кримінальному провадженні за допомогою угоди про примирення можливе у разі дотримання таких умов: скоєний злочин підпадає під визначений перелік злочинів; процедуру може бути ініційовано виключно потерпілим або правопорушником; процедуру може бути ініційовано до виходу суду до нарадчої кімнати для ухвалення вироку; дотримання принципів проведення медіації; процедура медіації проводиться тільки уповноваженими та незалежними особами.

Станом натепер в Україні підстави для проведення медіації у кримінальному процесі закріплені лише в КПК України. При цьому ні кримінально-процесуальне законодавство, ні окремий закон про медіацію не містить детальної регламентації процедури медіації, що вказує на необхідність удосконалення законодавчого закріплення інституту медіації в кримінальному процесуальному законодавстві.

\section{Література}

1. Смітієнко 3.Д. Медіація як кримінально-процесуальна категорія та їі застосування в кримінальних провадженнях щодо неповнолітніх. Зовнішня торгівля: економіка, фінанси, право. 2015.
Протидія злочинності: проблеми практики та науково-методичне забезпечення

№ 4. C. 130-139. URL: http://zt.knteu.kiev.ua/ files/2015/4(81)/Smytienko.pdf.

2. Кримінальний процесуальний кодекс України : Закон України від 13.04.2012 р. № 4651-VI. Дата оновлення: 14.01.2021. URL: https://zakon.rada.gov.ua/ laws/show/4651-17\#Text.

3. Кримінальний кодекс України : Закон України від 05.04.2001 р. № 2341-ІІІ: Дата оновлення: 30.12.2020. URL: https://zakon.rada.gov.ua/laws/ show/2341-14\#Text.

4. Ухвала Заводського районного суду м. Дніпродзержинська Дніпропетровської області від 16.01.2020 року. Справа № 208/8462/19. URL: http: / / reyestr.court.gov.ua/Review/87736877.

5. Ухвала Оболонського районного суду м. Києва від 20.06.2018 року. Справа № 756/6864/18. URL: http:// reyestr.court.gov.ua/Review/74806227.

6. Присяжнюк А. Медіація: завтрашня альтернатива чи нездійсненна мрія? URL: https://zib.com.ua/ ua/print/137025-mediaciya_zavtrashnya_alternativa_ chi_nezdiysnenna_mriya.html.

7. Новак Р.В. Кримінальне провадження на підставі угод в Україні : дис. ... канд. юрид. наук : спец. 19.00.09. Харківський національний університет ім. В.Н. Каразіна. Харків, 2015. 214 с. URL: http:// dspace.univer.kharkov.ua/bitstream/123456789/10850/ 6/diss_Novak.pdf.

8. Ухвала Дунаєвецького районного суду Хмельницької області від 08.10.2019 року Справа № 674/1473/19. URL: http://reyestr.court.gov.ua/ Review/84866702.

9. Ткачук А.Ю., Чернова Є.Р. Медіація у кримінальному процесі. Молодий вчений. 2018. № 5(2). C. 649-652. URL: http://nbuv.gov.ua/UJRN/ molv_2018_5\%282\%29_71.

10. Коваль Р.Г. Актуальні питання впровадження відновного правосуддя в правову систему України. Щоквартальний бюлетень «Відновне правосуддя в Україні». 2007. № 1 (5). С. 9-13. URL: https:// issuu.com/uccg/docs/vol.1_5.

11. Турман Н.О. Медіація в кримінальному процесі: шляхи удосконалення чинного законодавства. Підпрuємництво, господарство і право. 2017. № 3. С. 276-280. URL: http://pgp-journal.kiev.ua/archive/2017/3/63.pdf.

12. Лапкін А.В. Участь прокурора в кримінальному провадженні на підставі угоди про примирення. URL: http://tlaw.nlu.edu.ua/article/view/62776/58260.

Гочачко І. М., студентка 2 року навчання магістерської програми «Право» Національного університету «Києво-Могилянська академія» 